Kinestetik : Jurnal Ilmiah Pendidikan Jasmani 5 (2) (2021)

Kinestetik : Jurnal Ilmiah Pendidikan Jasmani

https://ejournal.unib.ac.id/index.php/kinestetik/index DOI : 10.33369/jk.v5i2.13828

\title{
REVIEW: THE EFFECT OF THE TEACHING GAME FOR UNDERSTANDING MODEL ON COGNITIVE ABILITY
}

\author{
Rinaldo $^{1 *}$, Beltasar Tarigan ${ }^{2}$, Tite Juliantine ${ }^{3}$ \\ ${ }^{123}$ Sport Education Program, Postgraduate school, Indonesian Education University, Bandung, \\ Indonesia
}

\section{Article Info}

Article History:

Received: December 2020

Revised: April 2021

Accepted: June 2021

Available online: June 2021

Keywords:

Physical Education, Teaching Game For Understanding (TGFU), cognitive abilities, decision skills

\begin{abstract}
Physical education has an important role in helping students develop quality skills. The Teaching Games for Understanding (TGFU) approach is a learning model that focuses on developing abilities through the form of basic playing concepts. TGFU is considered to have an influence in improving learning skills, especially in the domain of cognitive abilities such as decision making. This study describes the effectsthe TGFU model of cognitive abilities. The design of this writing is study literature review. The results of several studies indicate an increase in cognitive abilities in students who apply the TGFU learning model in the implementation of sports and games.
\end{abstract}

Corresponding address: J1. Dr. Setiabudi No.229, Isola, Kec.

Sukasari, Kota Bandung, Jawa Barat

* Corresponding email: rinaldonaldo93@gmail.com
ISSN 2685-6514 (Online)

ISSN 2477-331X (Print) 


\section{INTRODUCTION}

Physical education is a subject that has a vital position in the development of human resources (HR)(Rink, 2013). Physical education in schools does not only provide understanding for students about the process of physical or movement activities, and also physical education at school is expectedable to deliver / equip students in quality development that includesother important elements such as cognitive competence(Lind et al., 2017). Cognitive ability is one of the objectives of learning outcomes expected from the learning process and to measure the extent to which students achieve the specified results.

Cognitive abilities This is expected to affect the quality of students, which in turn will have an impact on the quality of humans throughout their lives, becauseCognitive approach focuses on students' thinking and reflective thinking(Liu, Mcbride, Xiang, \& Scarmardo-rhodes, 2017). There are things that are used as a cognitive basis when students think critically, namely thinking about how to combine information that has been collected from various sources and different perceptions, to make rational decisions that can later be explained and defended.(Abdullah, Badiei, Sulaiman, \& Baki, 2014).

The learning model is a step used in learning activities as a reference for educational actors in achieving one goal(Rodríguez-negro \& Yanci, 2019). Each learning model includes different components, one of which is Teaching Game For Understanding (TGFU) with cognitive domain priority through decision-making abilities in game concepts(Gurvitch \& Metzler, 2013). TGFU is a learning approach model designed to prioritizeon a tactical approach regardless of the technique used, developing creativity to play, and the accuracy of decision making in games (Johnson \& Walker, 2016). An important element of TGFU is to provide opportunities in students to develop thinking such as critical thinking, making decisions and solving problems(Harvey \& Jarrett, 2014)

The TGFU learning model strategy is considered appropriate for various school levels and in line with physical education programs that aim to develop cognitive abilities in students. Recent studies have shown a beneficial effect of physical activity on cognitive function. So that the learning approach with TGFU is expectedwill improve the quality of physical education that focuses on cognitive abilities.

\section{METHODS}

The design of this writing is a memorial literature review studymake reference from membResources with keywords in 2 languages, namely Indonesian and English and using the PRISMA guideline literature search flowchart(Moher et al., 2009). With the publication time of the last 10 years, namely 2010-2020. The search was conducted with keywords in the form of "model approach."Teaching Game For Understanding (TGFU)"," Cognitive abilities "," decision making "," TGFU in Physical Education ". The references used are international and national journals published including on Google Scholar, Science Direct, Elsevier, Taylorandfrancis, Pubmed and Springerlink. Then extracted with inclusion criteria, which include 1) Publication year 2010-2020; 2) Full access text; 3) National indexed (SINTA) or international (Schimagojr). The search results obtained 9 articles of the original type of research with mixed-methods quasi-experimental pre-test and post-test 
(1), qualitative: discource analysis (1), quantitative (3), experiment: factorial design (2) mixed: quantitative ( 1) quasiexperimental (1).

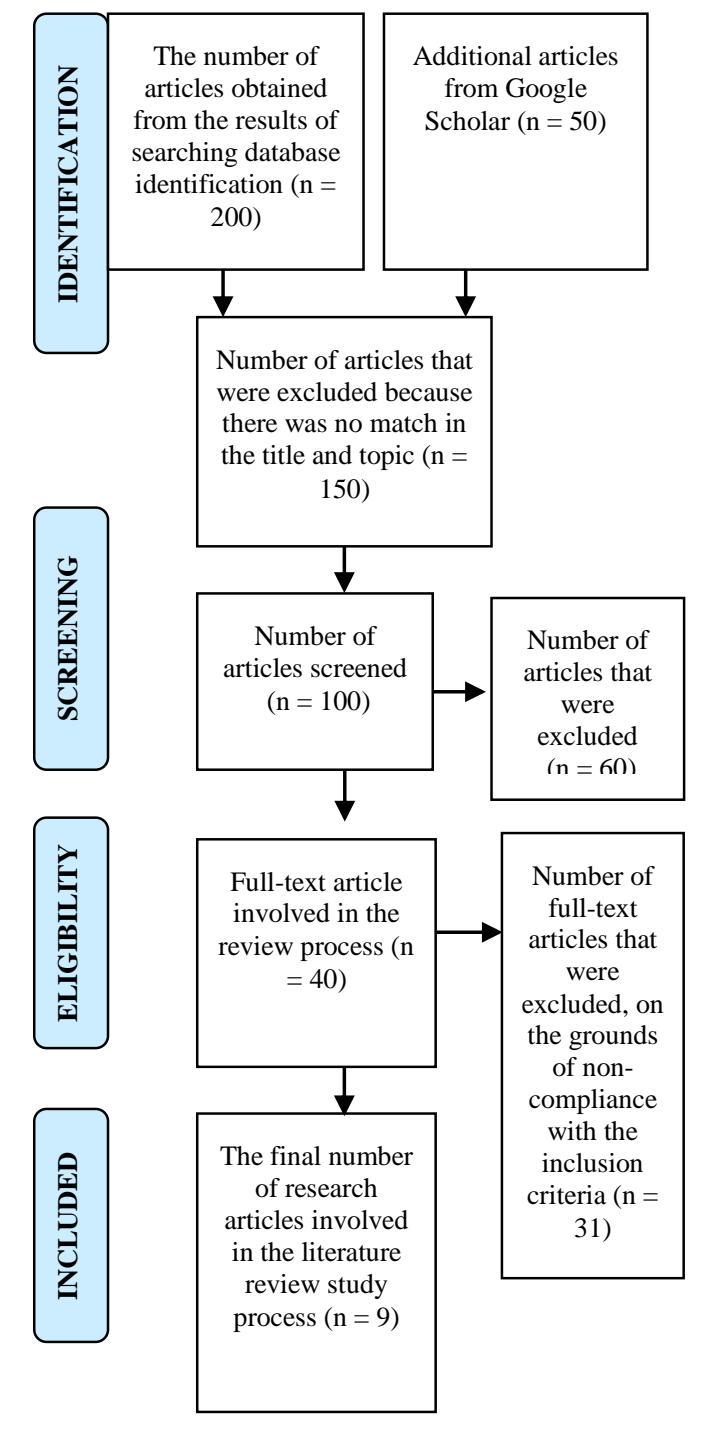

Ficture 1. Literature Search Flowchart

\section{RESULTS AND DISCUSSION}

Of the nine studies obtained, eight studies showed significant results in improving the cognitive performance domain in the form of decision making, while one other study showed different results, namely that there was no significant difference between the two models compared in the study. This study is more aimed at applying the TGFU model in physical education learning in the context of primary and secondary education schools.

Studies in Spain show an increase in the decision making of the TGFU study group. These results are seen from two main aspects, namely psychological aspects and interviews in the game of attack (invasion). The pre-test score of $\mathrm{M}$ $=1.54$ and the post-test $\mathrm{M}=7.50(\mathrm{P}$ $<0.05$ )(Morales-Belando, Calderón, \& Arias-Estero, 2018). In line with this study, the TGFU learning model also showed an increase in cognitive abilities in the critical thinking aspect seen from interactions in solving problems in motion situations in invasion games ( $\mathrm{P}$ $<0.05$ )(Ikbal, Yudiana, \& Juliantine, 2019).

Studies in Greece show a cognitive improvement seen from the aspect of meta-cognitive behavior in elementary school students. The results were seen from the pre-intervention test via think-aloud protocols, the results showed that the pre-intervention value was $5.63 \%$ and the post-intervention value was $22.5 \%$. These results indicate the TGFU learning model is effective in improving students' cognitive abilities in volleyball games(Chatzipanteli, Digelidis, \& Karatzoglidis, 2015). Another study in Spain showed that there was a better effect in the TGFU group when making decisions on passing and throwing skills in basketball games. Results are averagepost-test experimental group 900 $(\mathrm{SD}=074)$ and average post-test control group 823 (SD108) 95\% Cl, $(\mathrm{P}=0.026)$ (Gil, Álvarez, Pizarro, \& Domínguez, 2019). Still in Spain, but with a different focus on the game, it is said that there is an increase in the cognitive abilities of students in the TGFU group through the observation results of the Game Performance Evaluation Tool (GPET) in soccer games. The data showed that the 
pre-test average result was 43.42 lower than the post-test $66.15(\mathrm{P}=0.050)$ (Pizarro, García-González, Cortés, Perla Moreno Arroyo, \& Domínguez, 2016).

A study in Malaysia showed that there was no significant difference in the comparison of the two group models, namely the TGFU group and the SDT group, seen from the results of learning movement skills in the decision-making process in badminton. Where the average post-test result of the TGFU model is $12.75(\mathrm{SD}=4.52)$ and the average SDT model is $12.62(\mathrm{SD}=4.34)(\mathrm{P}>0.05)$ (Nathan, 2016).A study in Canada states that the results of the comparison of the TGFU learning model approach have the same knowledge structure pattern as the activity framework created by Mohan (1986) and is commonly used in science learning. These results are evidenced by the cognitive abilities of students in making decisions in physical education learning. So it can be concluded that the TGFU learning model is considered positive and has an influence on the cognitive enhancement of students in physical education(Slater \& Butler, 2015).

A study in Spain showed a significant difference in cognitive abilities in the aspects of decision making in the TGFU learning model compared to the Direct Instruction (DI) model. The average score of the post-test results of the TGFU model students was 9.00 (SD $=0.74)$ and the mean score of the posttest results of the students in the direct learning model was $0.25(\mathrm{SD}=0.57)(\mathrm{P}$ $<0.001$ (Sierra-Ríos, Clemente, Rey, \& González-Víllora, 2020). In Scotland, there is a significant difference in the TGFU learning model compared to the direct learning model that focuses on techniques in the game of movement with the ball and without the ball. The average score of movement with the ball in the TGFU model was higher, namely 17.00 $(\mathrm{SD}=7.03)$, while the average score of movement with the ball in the Direct Instruction (DI) model was 9.25 (SD = 6.71) $(\mathrm{P}<0.05)$ and the average score The average score of the movement without the ball in the TGFU model is also higher, namely $39.12(\mathrm{SD}=5.46)$ compared to the average score without the ball in the Direct Instruction (DI) model $17.87 \quad(\mathrm{SD}=4.85) \quad(\mathrm{P}$ $<0.001)($ Gray \& Sproule, 2011).

\section{CONCLUSION}

Of the nine studies, it shows that the TGFU learning model is considered to have a significant influence in improving students' cognitive abilities in the aspects of decision making in primary and secondary school physical education. In addition, the TGFU model can also have an influence through various types of sports media and games in physical education.Decision making is one of the basic pillars of developing a game, so it is suggested that the TGFU model be applied from the beginning of elementary school. In addition, the development of cognitive abilities will also have an effect on increasing the knowledge of tacticaltechnical skills needed in every physical education game. With that, the TGFU learning model that focuses on improving cognitive abilities in the aspect of decision-making abilities is expected to be oriented towards comprehensive learning, giving students the opportunity to make their own decisions.

\section{REFERENCES}

Abdullah, B., Badiei, M., Sulaiman, T., \& Baki, R. (2014). Enhance Critical Thinking in Physical Education among Malaysian University Students, 4(5), 198-203. https://doi.org/10.5923/j.sports.2014040 5.07

Chatzipanteli, A., Digelidis, N., \& Karatzoglidis, C. (2015). Physical 
Education and Sport Pedagogy A tactical-game approach and enhancement of metacognitive behaviour in elementary school students. Physical Education and Sport Pedagogy, (February 2015), 37-41. https://doi.org/10.1080/17408989.2014. 931366

Gil, V. M. G., Álvarez, F. D. V., Pizarro, A. P., \& Domínguez, A. M. (2019). Questioning as a fundamental tool for physical education students to develop decision-making skills. Movimento, 25(1). https://doi.org/10.22456/19828918.86547

Gray, S., \& Sproule, J. (2011). Developing pupils' performance in team invasion games. Physical Education and Sport Pedagogy, 16(1), 15-32. https://doi.org/10.1080/1740898090353 5792

Gurvitch, R., \& Metzler, M. (2013). Instructional Models, 30-37.

Harvey, S., \& Jarrett, K. (2014). A review of the game-centred approaches to teaching and coaching literature since 2006. Physical Education and Sport Pedagogy, (December 2014), 37-41. https://doi.org/10.1080/17408989.2012. 754005

Ikbal, A. M., Yudiana, Y., \& Juliantine, T. (2019). The Effect of Learning Model and Critical Thinking Skills to Solve Motion Situation Problem Ability in Invasion Game, 11(Icsshpe 2018), 9296. https://doi.org/10.2991/icsshpe18.2019 .26

Johnson, I. L., \& Walker, E. R. (2016). Teaching Games for Understanding: Building a Physically Literate Individual. Journal of Physical Education, Recreation \& Dance, 3084(July). https://doi.org/10.1080/07303084.2016. 1192922

Lind, R. R., Geertsen, S. S., Ørntoft, C., Larsen, M. N., Dvorak, J., Ritz, C., \& Krustrup, P. (2017). Improved cognitive performance in preadolescent Danish children after the school-based physical activity programme " FIFA 11 for Health " for Europe - A clusterrandomised controlled trial Improved cognitive performance in preadolescent Danish children af, 1391(November). https://doi.org/10.1080/17461391.2017. 1394369

Liu, J., Mcbride, R. E., Xiang, P., \& Scarmardo-rhodes, M. (2017). Physical Education Pre-service Teachers , Understanding , Application , and Development of Critical Thinking Physical Education Pre-service Teachers ' Understanding ,. Quest, 00(00), 1-16. https://doi.org/10.1080/00336297.2017. 1330218

Moher, D., Liberati, A., Tetzlaff, J., Altman, D. G., Altman, D., Antes, G., ... Tugwell, P. (2009). Preferred reporting items for systematic reviews and metaanalyses: The PRISMA statement. PLoS Medicine, 6(7). https://doi.org/10.1371/journal.pmed.10 00097

Morales-Belando, M. T., Calderón, A., \& Arias-Estero, J. L. (2018). Improvement in game performance and adherence after an aligned TGfU floorball unit in physical education. Physical Education and Sport Pedagogy, 23(6), 657-671. https://doi.org/10.1080/17408989.2018. 1530747

Nathan, S. (2016). Badminton instructional in Malaysian schools: a comparative analysis of TGfU and SDT pedagogical models. SpringerPlus, 5(1). https://doi.org/10.1186/s40064-0162872-3

Pizarro, A. P., García-González, L., Cortés, Á. M., Perla Moreno Arroyo, M., \& Domínguez, A. M. (2016). Application of an intervention program to improve tactical understanding in indoor football: A study conducted in an educational context. Movimento, 22(1), 51-62. https://doi.org/10.22456/19828918.55024

Rink, J. E. (2013). Measuring teacher effectiveness in physical education. Research Quarterly for Exercise and Sport, 84(4), 407-418. https://doi.org/10.1080/02701367.2013. 844018

Rodríguez-negro, J., \& Yanci, J. (2019). Which instructional models influence 
more on perceived exertion, affective valence, physical activity level, and class time in physical education? Educational Psychology, 0(0), 1-14. https://doi.org/10.1080/01443410.2019. 1613516

Sierra-Ríos, J. V., Clemente, F. M., Rey, E., \& González-Víllora, S. (2020). Effects of 6 weeks direct instruction and teaching games for understanding programs on physical activity and tactical behaviour in $\mathrm{u}-12$ soccer players. International Journal of Environmental Research and Public Health, 17(14), 1-14. https://doi.org/10.3390/ijerph17145008

Slater, T., \& Butler, J. I. (2015). Examining connections between the physical and the mental in education: A linguistic analysis of PE teaching and learning. Linguistics and Education, 30, 12-25. https://doi.org/10.1016/j.linged.2015.03 .006 